\title{
Ultrastructure of synovial cells in vitro
}

\author{
A. MARY GLEN-BOTT \\ Department of Anatomy, St. Thomas's Hospital Medical School, London, S.E.1
}

The ultrastructure of synovial membrane cells in situ has been described by Barland, Novikoff, and Hamerman (1962) and by Davies and Palfrey (1971) in human material; Davies and Palfrey (1966) and Ghadially and Roy (1969) have reported similar studies in animals: their findings indicate that the cells are connective tissue cells specialized to carry out a secretory or an absorptive function. Vaubel $(1933 a, b)$ has shown that cells grown from explants of synovial membrane actively produce mucin and has suggested that they are specific 'synovioblasts' rather than generalized connective tissue cells. It seems possible that the functions of synovial cells may be determined by locally acting factors. The present investigation has been undertaken to study the effects of trypsinization, suspension in a fluid medium, and subsequent culture on the ultrastructure of such cells.

\section{Materials and methods}

Specimens were obtained from the knee joints of ten rabbits of both sexes weighing between 1.7 and $3.6 \mathrm{~kg}$., using a method based on those of Fraser and Catt (1961) and Fraser and McCall (1965).

\section{WASHING}

The knee joints of eight rabbits were used. A preliminary wash with calcium and magnesium free saline was attempted; 1 to $5 \mathrm{ml}$. were injected into each joint but on no occasion was enough fluid recovered to allow examination of its cell content. Pancreatic trypsin (Difco), 1 to $2 \mathrm{ml}$. of an 0.25 per cent. solution at $37^{\circ} \mathrm{C}$. was injected into each joint and left for 15 to 20 minutes. The joint was then washed, using two cannulae, with $4 \mathrm{ml}$. of Eagle's minimal essential medium; this contained glucose, amino acids, and vitamins dissolved in Earle's salt solution (Eagle, 1959), pH 7.8; to this was added crystalline potassium penicillin $100 \mu \mathrm{g} . / \mathrm{ml}$., streptomycin sulphate $100 \mu \mathrm{g} . / \mathrm{ml}$. (Glaxo), and 10 per cent. foetal calf serum (Microbiological Associates, Bethesda, Md.). From each joint 1 to $5 \mathrm{ml}$. of fluid were recovered.

\section{ELECTRON MICROSCOPY}

Washings from three rabbits were prepared immediately, the material from both joints of each rabbit being combined. The fixative was 5 per cent. glutaraldehyde in phosphate buffer at pH 7.3. Two specimens were centrifuged and then $5 \mathrm{ml}$. of chilled fixative was added to the deposit, re-suspended, and left for 4 hours at $4^{\circ} \mathrm{C}$.

The third specimen was fixed for 2 hours at $4^{\circ} \mathrm{C}$. after the addition of 5 per cent. glutaraldehyde to a final concentration of 2 per cent. Specimens were washed four times by centrifugation and re-suspension in a 10 per cent. solution of sucrose in phosphate buffer; this was followed by a 1 per cent. solution of osmium tetroxide in veronal acetate buffer for 1 to 2 hours. They were dehydrated in ethyl alcohol and re-suspended in propylene oxide before embedding in araldite (Sabatini, Bensch, and Barrnett, 1963).

Araldite sections for optical microscopy were cut at a thickness of $1 \mu \mathrm{m}$. and stained with Azur II methylene blue (Richardson, Jarett, and Finke, 1960). Thin sections on uncoated copper grids were stained with uranyl acetate (Barnett and Palfrey, 1965).

\section{CELL CULTURES}

Eight washings from five rabbits were incubated at $37^{\circ} \mathrm{C}$. for 1 to 48 hours. Eagle's medium supplemented with 10 per cent. foetal calf serum was added to some cultures. Seven cultures were incubated in 'Leighton' tubes containing a sheet of Melinex (I.C.I.), a transparent polyester (Firket, 1966). In each case the cells attached and spread out on the Melinex sheet. The eighth specimen was incubated in five plastic embedding capsules for 4 hours at $37^{\circ} \mathrm{C}$. The cultures in plastic embedding capsules were fixed after 4 hours' incubation by the addition of chilled 2 per cent. glutaraldehyde to the centrifuged deposit and were left for 4 hours at $4^{\circ} \mathrm{C}$. before dehydration and embedding. Four Melinex cultures contained an insufficient number of cells to warrant further examination: of the three successful cultures, one was fixed in methanol after 48 hours' incubation and stained with Giemsa for optical microscopy, and two were fixed by immersion for 4 hours in 5 per cent. glutaraldehyde solution at $4^{\circ} \mathrm{C}$., one after 24 hours and the other after 48 hours incubation. The Melinex sheets with the attached cells were embedded in araldite using the flat-face method of Sheffield (1965).

SYNOVIAL MEMBRANE

Specimens were obtained from three joints after the washing procedure. One joint was injected with a 2 per cent. solution of glutaraldehyde before the specimen was taken; 
all specimens were immediately fixed in chilled 5 per cent. glutaraldehyde solution. Two rabbits were given an injection of trypsin heated to $37^{\circ} \mathrm{C}$. into one knee joint and 15 minutes later both joints were injected with chilled 5 per cent glutaraldehyde solution. Slices of synovial membrane were obtained from these joints and kept in fixative for 4 hours at $4^{\circ} \mathrm{C}$. before embedding.

\section{Results}

Sections examined by optical microscopy showed the varied appearance of tissue taken from different sites. A specimen from the ligamentum mucosum consisted of a villus rich in fat cells and blood vessels with a cellular synovial membrane. The second showed loose connective tissue with flat surface cells, and the third, from the deep surface of the quadriceps muscle, was cellular and thrown into folds by contraction of the underlying muscle.

Electron microscopy revealed the classical picture of synovial membrane, consisting of two to four cells on a supporting connective tissue. Collagen fibres lay in bundles or individually between the cells; their

FIG. 2 Cell lying on synovial surface after trypsinization. The plasma membrane merges with fine filaments and collagen fibres where it is cut obliquely. $\times 24,000$

FIG. 1 Normal synovial membrane from control rabbit. There is a type A cell on the left and a type B cell on the right. $\times 12,000$
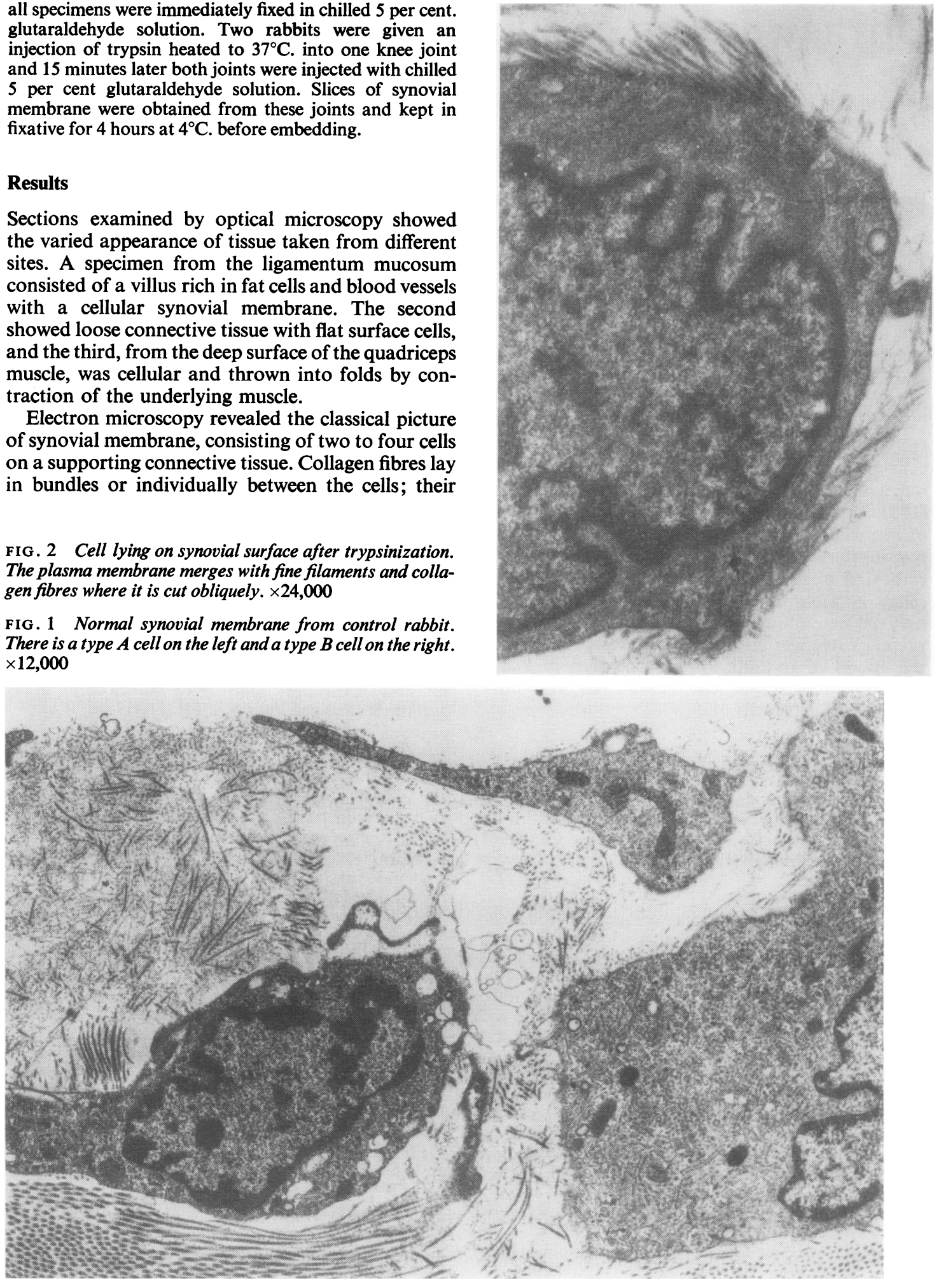
diameter decreased towards the joint surface where they were associated with unbanded fibrils (diameter circa. $10 \mathrm{~nm}$.). A fine fibrillar material surrounded the surface cells filling in gaps of up to $25 \mu \mathrm{m}$. between them (Fig. 1). The cells varied in shape from oval or irregular to thin and flattened. The detailed fine structural appearances did not differ from other published accounts.

\section{Synovial membrane treated with trypsin}

Optical microscopy revealed a synovial membrane which was remarkably acellular; there were gaps of up to $100 \mu \mathrm{m}$. between surface cells.

Electron microscopy confirmed that there were surface areas with fine fibrillar material typical of synovial membrane but lacking cells. In other places the tissue had a normal appearance, but in yet other areas the remaining cells had an extremely irregular shape. The cytoplasm of most cells appeared normal but the plasma membrane of some surface cells was cut obliquely merging with both fibrils and collagen fibres (Fig. 2).

\section{Synovial membrane treated with trypsin and then washed}

Optical microscopy revealed either dense or loose connective tissue and some flat cells underlying the synovial membrane. The synovial surface was free of cells for distances up to $300 \mu \mathrm{m}$. and some of the remaining cells had irregular ill-defined outlines. Free globules of fat were also seen on the surface.

Electron microscopy revealed a paucity of surface cells as in the specimens treated with trypsin alone. Some remaining surface cells had outlines which were even more irregular; they were covered with fine cytoplasmic processes and a greatly increased electron density obscured their ultrastructure (Fig. 3). Bundles of collagen fibres were seen at the surface.

\section{Joint washings fixed immediately}

By optical microscopy groups of irregular cells with a foamy cytoplasm lay between a variable number of red cells. Electron microscopy revealed that a majority of the cells had an increased density, obscuring their ultrastructure. Their shape was irregular; numerous finger-like cytoplasmic processes of circa. $100 \mathrm{~nm}$. width protruded from their surface for lengths up to $2 \mu \mathrm{m}$. (Fig. 4, overleaf). The increase in density was variable but affected both nucleus and cytoplasm. There was no evidence that different methods of fixation or changes in staining technique had any appreciable effect on the degree of density. The nuclei could be seen to vary in shape and appearance. The chromatin of some nuclei was not heavily condensed; in others it was condensed peripherally or in small masses scattered throughout the nucleus.

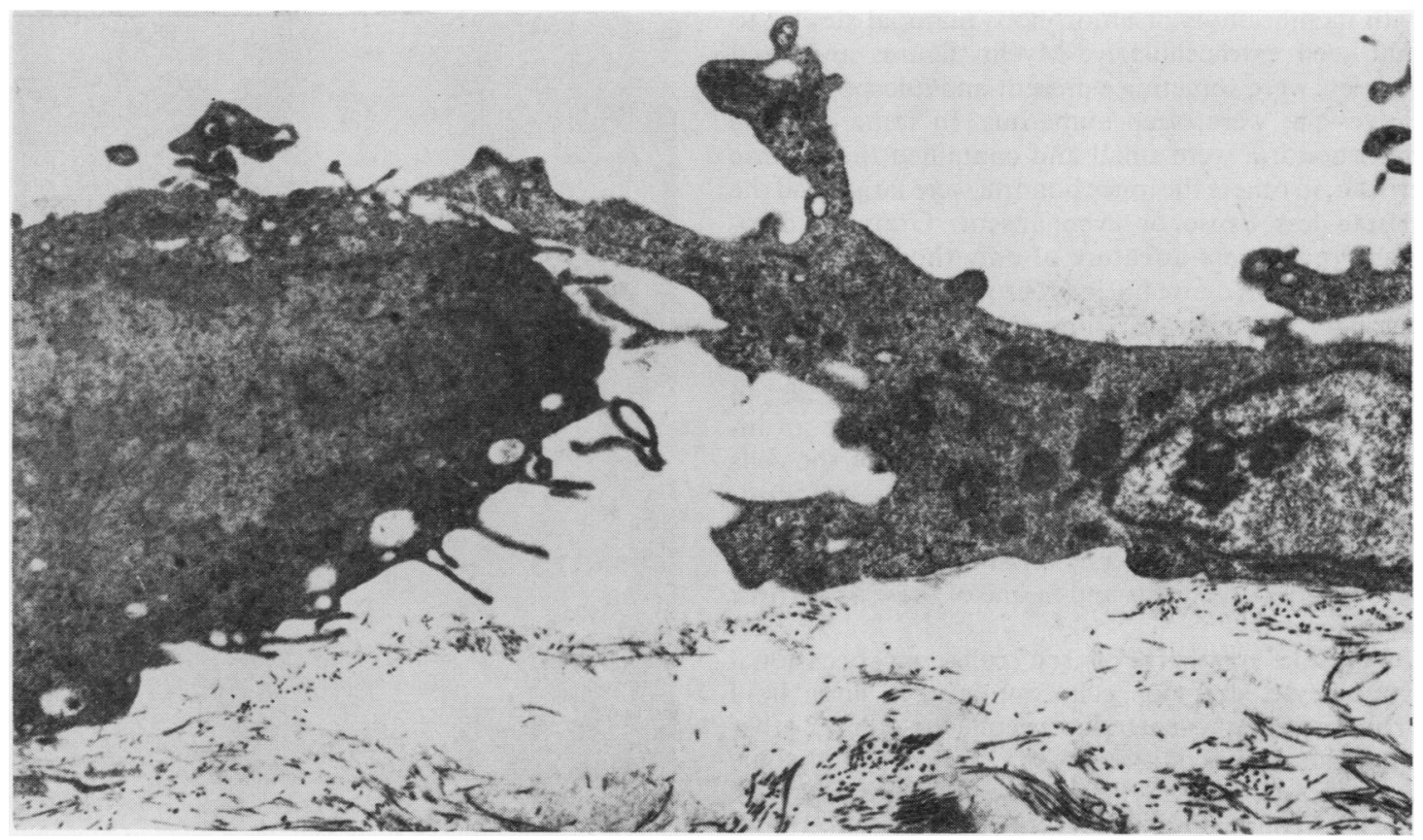

FIG. 3 Synovial membrane taken after washing. A rounded cell with increased density on the left has many fine cytoplasmic protrusions. The cell on the right has an irregular outline but is otherwise of normal appearance. $\times 12,000$ 


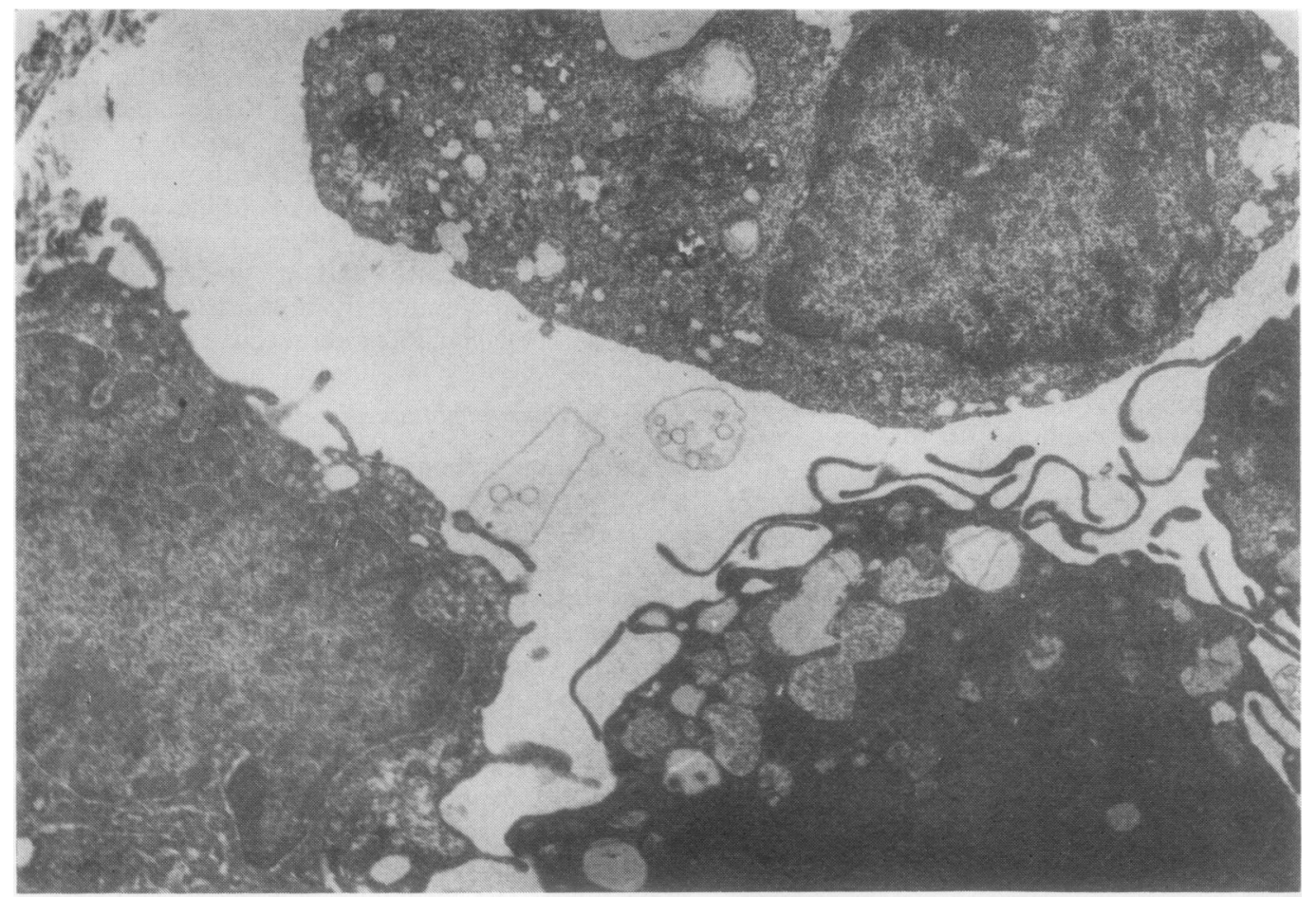

FIG. 4 Cells from synovial washings. One very dense cell is similar to the dense cell in Fig. $3 . \times 12,000$

The cytoplasm contained large vesicles, often filled with membranous or amorphous material similar to that seen extracellularly. Myelin figures and lipid droplets were sometimes present and micropinocytotic vesicles were often numerous. In some cells the mitochondria were small and contained thick dense cristae; in others the mitochondria were larger and the cristae less dense or even absent. Granular cytomembranes were a feature of only those cells which contained less dense nuclear chromatin while a Golgi complex was seen occasionally in any type of cell. Microtubules were rarely seen but filaments were distributed through the cytoplasm of many cells; in some they were packed so tightly as to give an increased density to the cytoplasm. Some of the cells with an overall increase in density and loss of ultrastructure contained fine cytoplasmic filaments near the nucleus (Fig. 5). Others contained tightly packed cytoplasmic organelles and in one of these a centriole was seen.

Variable numbers of red cells, an occasional lymphocyte, and one cell containing a large lipid droplet were present. Loose collagen fibres, other amorphous material, pieces of dead cells, and some dense whorled bodies lay between the cells and were often surrounded by cytoplasmic processes of more healthy cells. A few very pale degenerate cells were seen (Fig. 6, opposite).

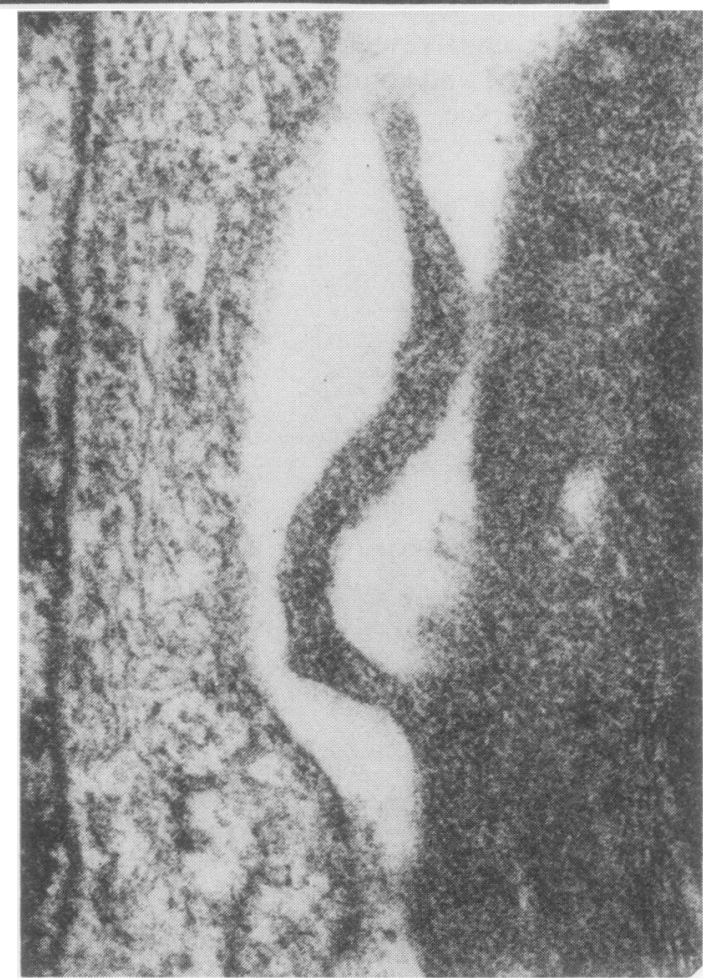

FIG. 5 Parts of two washed cells. A dense cell with illdefined structure on the right contains a mass of filaments; on the left a paler cell also contains some cytoplasmic filaments. $\times 78,000$ 


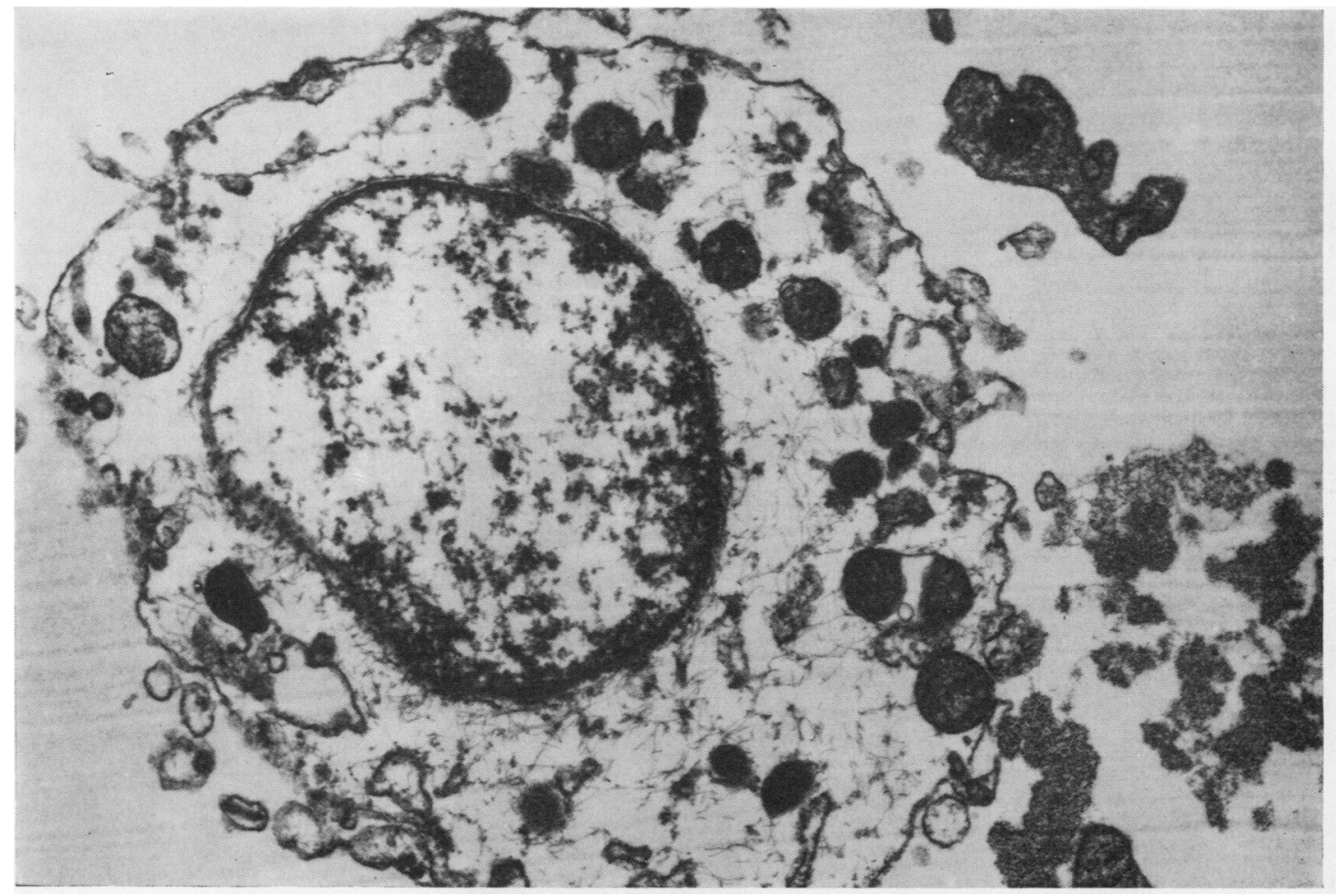

FIG. $6 A$ washed cell with decreased electron density and loss of structure. $\times 20,000$

\section{Joint washings incubated at $37^{\circ} \mathrm{C}$. for 4 hours}

Examination by optical microscopy of sections cut from the 4-hour suspension cultures revealed groups of cells which were slightly larger and less varied in shape than cells fixed directly. In the electron microscope these cells had fewer cytoplasmic processes and more regular outline. The nucleus was usually indented but not often deeply folded; the chromatin was condensed in masses which lay on the nuclear membrane or free inside the nucleus. The appearance of the cytoplasm was variable: vesicles of different shapes and sizes gave a fenestrated appearance to some cells; some were empty but others contained fragments of dead cells, amorphous material, or myelin figures. Material with the same structure was also seen extracellularly. In many cells masses of tightly packed filaments gave an appearance of increased density to the cytoplasm (Fig. 7). In other areas the cytoplasm contained mitochondria in normal distribution; granular cytomembranes were rarely seen but free ribosomes, a Golgi complex, and microtubules were often present. Red blood cells were numerous in this preparation together with a few lymphocytes, polymorphonuclear leucocytes, and plasma cells. Occasional pale degenerate cells were also seen.

\section{Cells cultured for 24 and 48 hours}

Examination by optical microscopy of the 48-hour culture showed cells containing many large vacuoles spread over the Melinex surface. In the electron microscope both the 24- and 48-hour cultures revealed very large cells containing many dense bodies. The cells in the 48-hour culture, which were more numerous than those of the 24-hour culture, were packed with large lipid-filled vesicles (Fig. 8). Pinocytotic vesicles were often numerous; the mitochondria were large and sometimes degenerate; free ribosomes were often seen and the Golgi apparatus was prominent. Cytoplasmic filaments were present in some cells but were not closely packed. The nuclei contained dispersed chromatin and often a nucleolus. Mitotic figures were not seen. Extracellular collagen fibres and some amorphous debris were also present.

\section{Discussion}

The varied appearance of synovial membrane taken from different sites has been described by Barnett, Davies, and MacConaill (1961). In the present study the fibrous and aerolar specimens contain very thin flattened synovial cells, whereas the cells overlying fatty tissue are often thick and rounded. 
The first description of the ultrastructure of the synovial membrane is given by Barland and others (1962) who describe cells of two structural types: some have numerous filopodia, many vesicles, and a prominent Golgi complex (Type A), while others, with a smoother outline, contain abundant granular cytoplasmic reticulum and fewer vesicles (Type B). It is generally agreed that the different morphology may be dependent on the functional activity of the cell (Ghadially and Roy, 1969) or the part of the cell which is sectioned (Davies and Palfrey, 1971). Type A cells, with a morphology similar to macrophages, takes up particles and larger cell fragments, and may be concerned with absorption. Type B cells, with many of the features of fibroblasts, may be concerned with the production of protein; their production of the hyaluronate protein complex has been extensively studied (Barland, Smith, and Hamerman, 1968). Synovial cells are likely to be concerned with the regulation of the composition of synovial fluid and the maintenance of the ordered structure of synovial membrane.

The origin of synovial cells is not established. Levene (1957) showed that experimental injury of
FIG. 7 Part of a washed cell cultured for 4 hours. Nuclear and cytoplasmic structure is well defined; masses of filaments give the cytoplasm an increased density. $\times 32,000$ rat synovial membrane was followed by regeneration of lining cells from the underlying connective tissue, uninjured surface cells playing no part in the repair.

The cells in the washing fluid from rabbit knee joints are thought to derive mainly from the synovial surface; they are morphologically similar to surface cells and lengths of surface are seen free of cells. Other cells in the washings are derived from blood; it is possible that connective tissue or cartilage cells are also present.

The effect of trypsinization is to release some cells from the synovial surface; the remaining cells are rounded or irregular in shape but show no other structural changes. When trypsinization is followed by washing, some of the cells, both in the washings and on the synovium, show further alterations. Many cells have numerous cytoplasmic protrusions with evidence of phagocytosis: similar changes have been seen in cultured rabbit kidney cells after trypsinization (A. M. Glauert, personal communication). Many cells also show varying degrees of increased electron density, sometimes associated with cytoplasmic filamentous masses.

Increased electron density is generally considered 


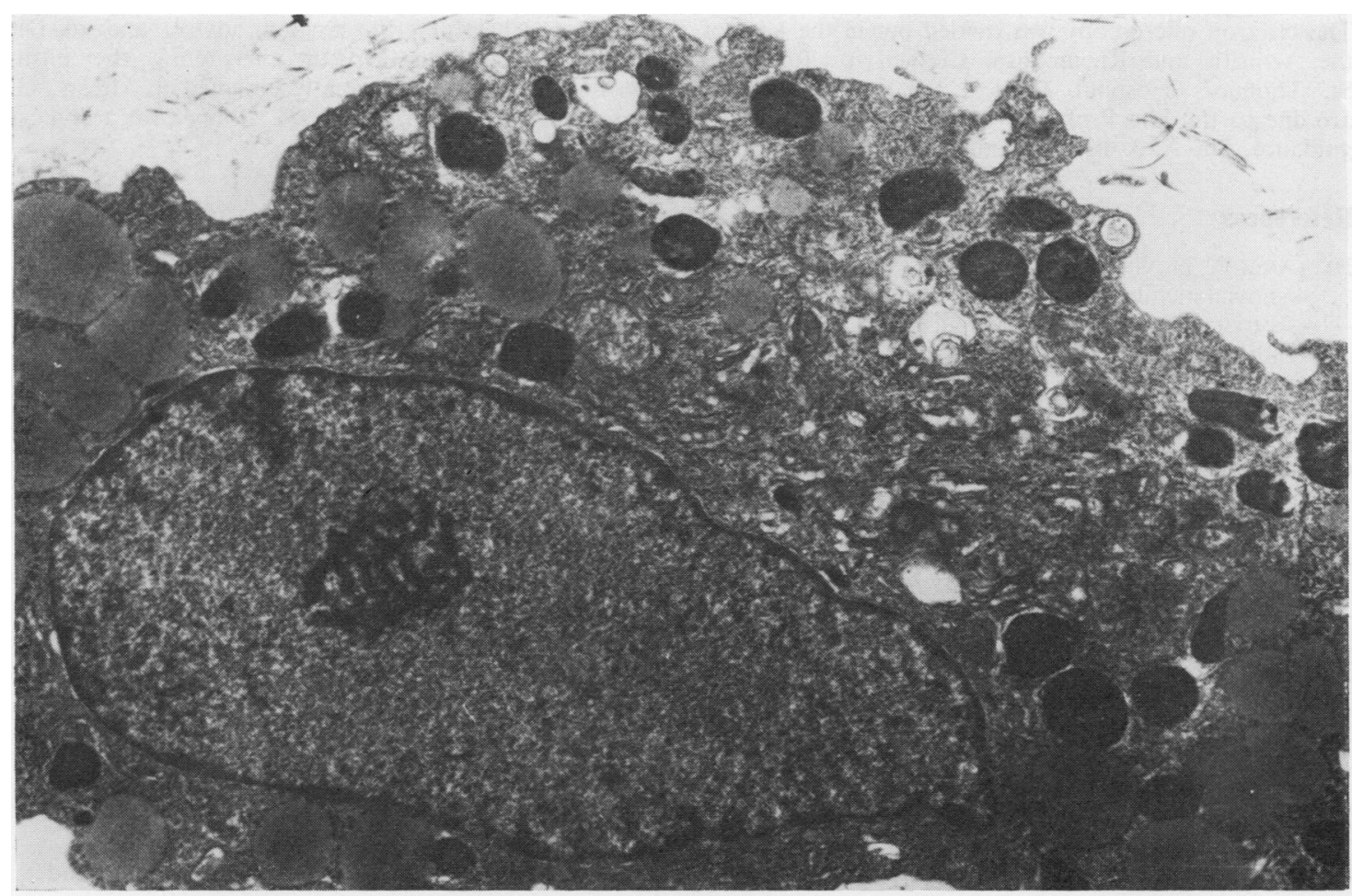

FIG. 8 A washed cell cultured on Melinex polyester sheeting for 48 hours. The cytoplasm contains large lipidfilled vesicles and dense bodies. $\times 12,000$

to indicate a degenerative process. Masses of cytoplasmic filaments have been seen occasionally in the dense cells of washings fixed immediately. The filaments are more numerous and distinct in many of the cells from the 4-hour culture. Similar filamentous masses are reported in many normal animal cells (Fawcett, 1966), in rabbit chondrocytes (Palfrey and Davies, 1966), and in degenerate human chondrocytes (Meachim and Roy, 1967). It is likely that the increased electron density of the washed cells may be due to a dissociation of cytoplasmic structures; the products of dissociation may reaggregate during culture, forming filamentous masses.

The cells in the 24- and 48-hour cultures are those attached to the Melinex surface. The numerous dense bodies, the lipid filled vesicles, and the prominent Golgi complex in these cells are similar to those described in cultured peritoneal macrophages by Cohn, Hirsch, and Fedorko (1966).

It can be concluded that significant alterations in the form and structure of these cells occur as a result of their altered environment. Cells, whose shape in the intact animal is determined by their position on the synovial surface, all become actively phagocytic when suspended in a fluid medium; they take on a round shape after 4 hours in culture and later some selected cells spread out over a smooth surface. Cells with the typical ultrastructure of synovial cells are recognizable at first but changes take place during culture resulting in a more uniform type of cell. It would seem unwise to draw conclusions about the nature of synovial cells from studies of their behaviour in conditions of tissue culture.

\section{Summary}

Cells washed from rabbit knee joints by trypsinization were examined in the electron microscope immediately, after 4 hours in suspension culture, and after 24 and 48 hours' culture on a flat surface. Pieces of synovial membrane were examined before the procedure started, after trypsinization, and after the washing procedure. The ultrastructure of many of the cells in the washing fluid was similar either to normal synovial cells or to the altered cells which remained on the synovial surface after washing; it was concluded that they were derived from the synovial membrane. Ultrastructural changes in the synovial cells could be attributed to trypsin, to washing, or to the cultural techniques used. These changes were substantial and suggest that the functional properties of cultured cells do not necessarily reflect their function in vivo. 
The electron microscopy was carried out in the Unit of the Arthritis and Rheumatism Council for Research, St. Thomas's Hospital Medical School. My thanks are due to the late Prof. D. V. Davies for his initial guidance, Dr. A. J. Palfrey, and the late Prof. C. H.
Barnett for helpful criticism and advice, and to Dr. Audrey Glauert for help in interpreting the ultrastructural changes. I am greatly indebted to Messrs. G. Maxwell, J. S. Fenton, and J. R. Cooper for technical assistance.

\section{References}

Barland, P., Novikoff, A. B., AND Hamerman, D. (1962) J. Cell Biol., 14, 207 (Electron microscopy of the human synovial membrane)

-, Smith, C., AND HAmerman, D. (1968) Ibid., 37, 13 (Localization of hyaluronic acid in synovial cells by radioautography)

Barnett, C. H., Davies, D. V., AND MacConaill, M. A. (1961) 'Synovial Joints: Their Structure and Mechanics'. Longmans, London

ANd Palfrey, A. J. (1965) J. Anat. (Lond.), 99, 365-375 (Absorption into the rabbit articular cartilage)

Conn, Z. A., HirsCh, J. G. AND FedorKo, M. E., (1966) J. exp. Med., 123, 747 (The in vitro differentiation of mononuclear phagocytes. IV. The ultrastructure of macrophage differentiation in the peritoneal cavity and in culture)

Davies, D. V., AND Palfrey, A. J. (1966) 'Electron microscopy of normal synovial membrane', in 'Studies on the Anatomy and Function of Bone and Joints', ed. F. Gaynor Evans, pp. 1-16. Springer, Berlin

- (1971) 'The fine structure of normal and rheumatoid synovial membrane', in 'Recent Advances in Rheumatology', ed. A. G. S. Hill. Butterworths, London

EAGLE, H. (1959) Science, 130, 432 (Amino acid metabolism in mammalian cell cultures)

FAwCETT, D. W. (1966) ‘An Atlas of Fine Structure. The Cell. Its Organelles and Inclusions.' Saunders, Philadelphia and London

FiRKET, H. (1966) Stain Technol., 41, 189 (Polyester sheeting (Melinex O), a tissue culture support easily separable from epoxy resins after a flat-face embedding)

Fraser, J. R. E., AND CATT, K. J. (1961) Lancet, 2, 1437 (Human synovial cell culture: Use of a new method in a study of rheumatoid arthritis)

— AND McCaLl, J. F. (1965) Ann. rheum. Dis., 24, 351 (Culture of synovial cells in vitro. Notes on isolation and propagation)

GhaDially, F. N., AND Roy, S. (1969) 'Ultrastructural of Synovial Joints in Health and Disease'. Butterworths, London

LEVENE, A. (1957) J. path. Bact., 73, 87 (The response to injury of rat synovial membrane)

MeAchim, G., AND Roy, S. (1967) Ann. rheum. Dis., 26, 50 (Intracytoplasmic filaments in the cells of adult human articular cartilage)

Palfrey, A. J., AND DAvies, D. V. (1966) J. Anat. (Lond.), 100, 213 (The fine structure of chondrocytes)

Richardson, K. C., JARETT, L., AND FinKe, E. H. (1960) Stain Technol., 35, 313 (Embedding in epoxy resins for ultrathin sectioning in electron microscopy)

Sabatini, D. D., Bensch, K., and Barrnett, R. J. (1963) J. Cell Biol., 17, 19 (Cytochemistry and electron microscopy. The preservation of cellular ultrastructure and enzymatic activity by aldehyde fixation)

SHEFField, H. G. (1965) Stain Technol., 40, 143 (A device for flat-face epoxy resin embedding of tissues and coverslip cultures)

VAUBEL, E. (1933a) J. exp. Med., 58, 63 (The form and function of synovial cells in tissue cultures. I. Morphology of the cells under varying conditions)

_ (1933b) Ibid., 58, 85 (The form and function of synovial cells in tissue cultures. II. The production of mucin) 